\title{
The Minangkabau house: architectural and cultural elements
}

\author{
A. Bahauddin, S. Hardono, A. Abdullah \& N. Z. Maliki \\ School of Housing, Building and Planning, Universiti Sains, Malaysia
}

\begin{abstract}
This paper studies the sustainable design and cultural elements that are found in the traditional Minangkabau house in Western Sumatera, Indonesia and in Negeri Sembilan, Malaysia. The matriarchal influence on the architecture features a unique regional style. The architecture is known to be laced heavily with cultural values, customs and rituals and reflects the people's understanding about designing architecture that is in harmony with nature. The house serves as a residence, a hall for family meetings, and for ceremonial activities. With the Minangkabau society being matrilineal, the house is owned by the women of the family who live there - ownership is passed from mother to daughter. The houses have dramatic curved roof structures with multi-tiered, upswept gables to mimic the horn of the buffalo. The objectives of this research are to analyse the matriarchal influence on the architecture; to investigate the architecture in terms of its sustainability issues as well as the traditional philosophy and cultural issues associated with the architecture. The methodology employed for this research includes reviewing the existing literature on the house to enable understanding of the space planning of the house. Other literature looks into cultural issues that comprise customs and traditions relating to the house supported by the field research in the Minangkabau villages in Malaysia and Western Sumatera. This is done simultaneously with the interview process of the locals and the visual data collection of the architecture. Architecturally, the house transpires that the dwelling-house is represented in the forms of space visualising the dwellers' culture. This research will ultimately venture into the understanding of the sustainability issues found in the design of the house and the sustainability of cultural beliefs applied in the rituals associated with the architecture.

Keywords: Minangkabau house, sustainable cultural and architectural elements.
\end{abstract}




\section{Introduction}

This paper investigates the sustainable cultural and architectural values of the Minangkabau houses both in Western Sumatera, Indonesia and Negeri Sembilan, Malaysia (figure 1). Traditional design and architecture is not directly influenced by the culture. The elements are in the culture itself such as by the rituals, traditions, philosophies, customs, politics, economy and social roles. These elements can influence the local architecture found in the space and the design relating to the environment. It can become the symbol of pride and sovereignty of the society (Yovita [1]). In the Malay Archipelago, the cultural elements have significant influence in shaping the architectural elements of the traditional houses to produce unique local architecture (Hanafi [2]). In Austronesia, the building of a home is not solely to serve as a shelter, but it is built and designed as a symbol of cultural pride and glory of a society (Fox [3]).

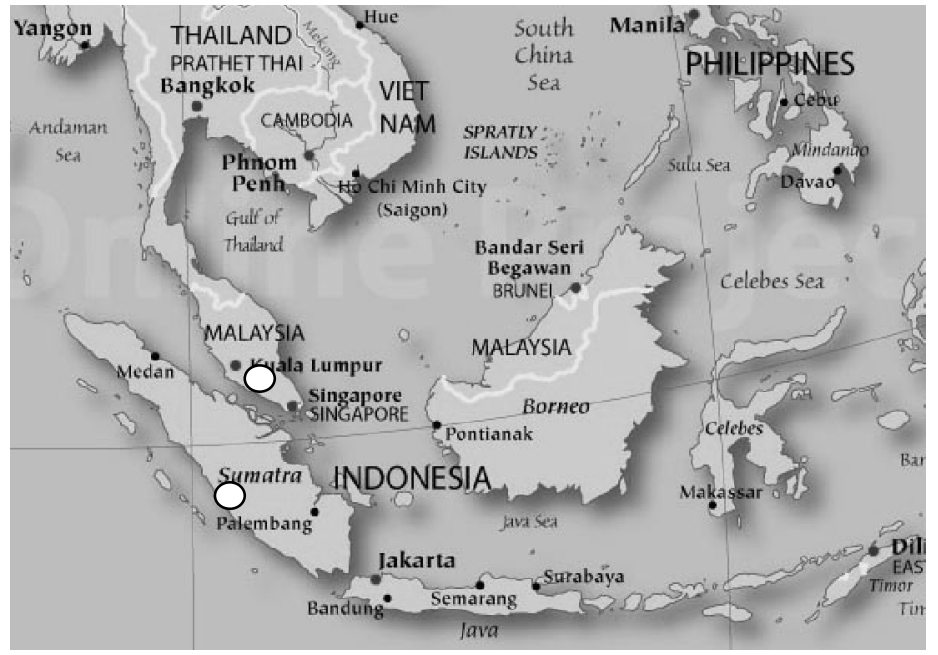

Figure 1: $\quad$ Map of Indonesia and Malaysia.

The Minangkabau culture has long been recognised and well known. The fame and glory of the Minangkabau cultural society has existed since 500 AD (Asri [4]). The culture lies in its unique architecture of traditional houses. According to Is [5], the features of the Minangkabau culture can be seen in the unique architectural manifestation. It features an identity in the distinctive interior design layout of the houses governed by the social and cultural relationships. The uniqueness and the beauty of this traditional architecture can be further witnessed in the architectural elements. They are mostly influenced by the cultural values of a traditional society that practices matrilineal role, an authority through the power of the maternal lineage (Soeroto [6]). In Indonesia, the Minangkabau society forms one of the largest ethnic groups that consist of people who practice the tradition of the world's largest matrilineal culture. This is 
further strengthened with its consistent system of culture and society (Gilbert [7]).

The Minangkabau people have lived in the provinces of Western Sumatera, Indonesia, known as the real Minangkabau. The areas are called the Wilayah Tiga consists of the Tanah Datar Region in Batu Sangkar, the Agam Region in Bukit Tinggi, and the Kota Lima Puluh Region in Paya Kumbuh (figure 2) (Asri [4]; Is [5]; Soeroto [6]; Jayatri [8]; Widya [9]).

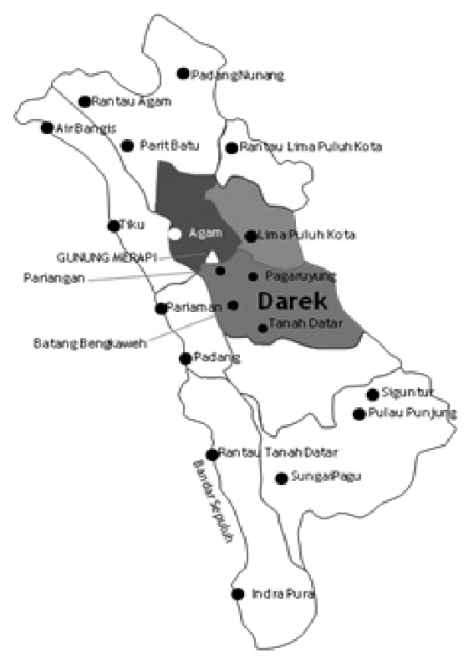

Figure 2: Western Sumatera Minangkabau region.

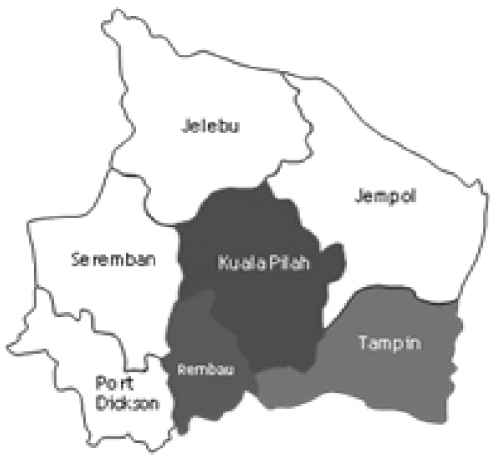

Figure 3: Negeri Sembilan Minangkabau region.

In Malaysia, the Minangkabau culture and society began in Negeri Sembilan in the 16th century after the massive migration of the Western Sumatera Minangkabau people throughout Southeast Asia (Adil [10]; Kim and Zima [11]; Ibrahim [12]). Negeri Sembilan is known as the Minangkabau region province (figure 3). The Minangkabau culture and architecture began to take root in Negeri Sembilan and remained so to this day since after the migration. However, the customs practiced by the Minangkabau society in Negeri Sembilan is known as the Perpatih custom named after the founder Datuk Perpatih from Western Sumatera. Both regions still practice the same traditions despite the difference in the names given to the traditions (Adil [10]).

\section{Objectives and methodology}

The objectives of this research are to analyse the matrilineal influence on the architecture; to investigate the architecture in terms of its sustainability issues as well as the traditional philosophy and cultural issues associated with the architecture. Previous studies are examined to identify the parameters for this 
paper. The initial observation found that there are differences in the physical characteristics of both the Minangkabau houses both in Western Sumatera and Negeri Sembilan albeit of the similar culture. This matter was investigated further concerning the ritual beliefs in house construction and matrilineal influence on the architectural elements and the interior space layout of both houses. The Minangkabau people adhere to the culture and traditions that have been practiced for a long time. The cultural activities involving matrilineal influences were studied (Nasroen [13]). These are then transposed into the architectural elements of the Minangkabau house. The Minangkabau community holds on firmly to the traditional philosophy of making the universe as a guide in underlying each traditional rules. It is further reinforced with the fieldwork done on the houses and a few have been selected in both areas as case studies. The case study is done through detailed interaction method with a study group to obtain the right data (Masoed [15]). Visual data and measured drawings were collected and documented. The interview was conducted simultaneously with the visual data collection as the data from the interview was used to interpret the architecture. The information obtained from the case study was documented into working drawings with an understanding of the Minangkabau customs.

\section{The Minangkabau customs}

Nasroen [13] stated that Minangkabau tradition is a rule and process of life that every person needs to go through in order to understand the meaning of life. The custom is not only being practiced in cultural ceremonies such as weddings, births, and deaths and so on, but also used as guidance in all aspects of life. It is the custom of individual and societal life conduct linked to philosophy, ritual, politic, economy, social and religious beliefs. People will be perfectly educated if the tradition is being followed. Nonetheless, the elements of Minangkabau tradition will not stand alone without learning how the harmony of the architecture and nature existed. Nature has become the source of the Minangkabau tradition. Thus, nature is considered as the teacher through a concept called Alam Takambang Jadi Guru - nature as teacher (Masoed [15]). The Minangkabaus are very respectful and loyal to the tradition. The deference of the people has been reflected on the design and architecture of the houses. The matrilineal line is mandated to own and inherit the houses. Thus, spaces have been designed according to the matrilineal needs since they are the permanent residents of the house. According to $\mathrm{Ng}$ [16], the circulation of the house has been designed at the convenience of the matrilineal occupants either during daily life activities or during traditional ceremonies.

Manggis [17] stated that the Minangkabau tradition teaches its people to live in harmony with nature. Every component of nature -sun, moon, rivers and plants - has specific functions to provide sustenance and joy to human beings. The tradition has modelled nature's functions to be adapted into the traditional rules. This has been translated into the architecture. They are seen specifically on the wall design formed with various motifs of plants, geometrical pattern of moon and sun and others. The house is also designed with different heights. 
Higher floor belongs to the leaders according to the hierarchy. Hakimy [18] stated that the Minangkabau tradition is divided into four levels. They are firstly, the real true tradition; secondly, the tradition that is being cultured, thirdly, the cultured tradition and lastly, the ritual. All these four traditions are divided into two stages. 'The real true tradition' and 'the tradition that is being cultured' are grouped in the first level, which is a fixed and unchangeable tradition. 'The cultured tradition' and 'the rituals' are grouped in the second level, a tradition that is changeable through agreement and consensus. The tradition that is not changeable is related to the elements of nature. The changeable tradition is linked to the human's behaviour that can vary based on situation and time as long as the tradition is beneficial to the society. The house can be seen to apply the tradition in the interior space layout especially for the women folk. The number of rooms in the house is determined by the number of daughters. Yet the room layout in this house is not necessarily built permanently, but can change and differentiate. According to $\mathrm{Ng}$ [16], a newly married daughter will be given a more special room. However, the room will not become her absolute property as the room will be given to the next newlywed daughter. Masoed [15] mentioned that the values of the tradition have been formed based on the balance and harmony derived from nature. The system of physical and natural rotation that is in order with the existence of its functions has become the guideline and inspiration to formed traditional values.

\section{The Minangkabau house in Western Sumatera}

The studies undertaken by others (Asri [4]; Is [5]; Widya [9]; Manggis [17]) stated that the design of the Minangkabau houses in Western Sumatera was greatly influenced by nature. The houses are different from other ethnic groups' traditional houses. They are easily recognised by their unique architectural features, especially the concave roof design that looks like buffalo horns or bumbung bergonjong (Idrus [19]) (figure 4 and figure 5).

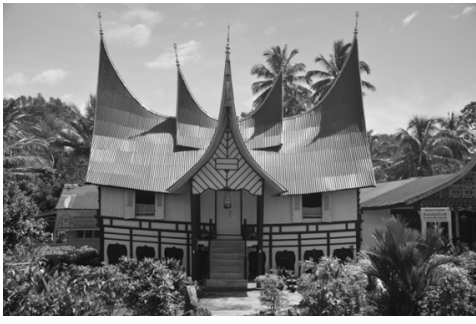

Figure 4: The Bundo Kanduang house.

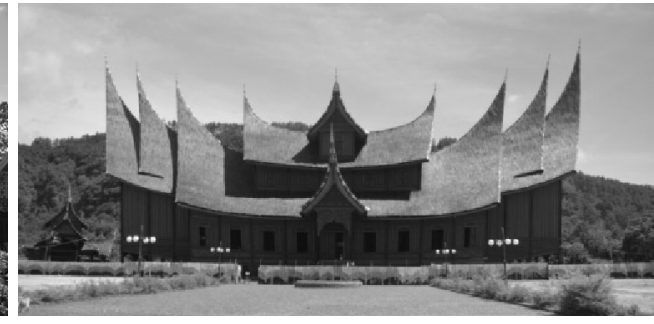

Figure 5: The Pagar Ruyung palace.

The Western Sumatera Minangkabau house is a traditional house used for living as well as a place for rituals or customary ceremonies. It can also be used for conference or communal meetings (Yovita [1]; Soeroto [6]). The house can be owned by a certain clan or certain individuals as the house is inherited from ancestors. It cannot be sold or bought like other inheritances such as farmland, 
paddy fields and plantations [6]. The house can accommodate more than one family that can be the family of the grandmother, the family of the mother and the family of the daughter, while the head of the house known as tungganai, will be appointed to lead the occupants (Erman et al. [20]).

There are two types of the Western Sumatera Minangkabau house designs (Widya [9]). They are based on the Koto Piliang district system and Bodi Caniago district system. Koto Piliang house is known as the Sitinjau Laut or 'towards the sea' which is located throughout the Tanah Datar region, while Bodi Caniago Minangkabau house known as the Rumah Gadang or 'big house' covers the entire region of Agam and Kota Lima Puluh (Asri [4]; Is [5]; Soeroto [6]; Jayatri [8]; Widya [9]). The difference between Koto Piliang house and Bodi Caniago can be seen on the porch at the side of the house. Koto Piliang house has balcony and a different floor height from the main house (figure 6).

The Bodi Caniago house does not have a balcony and the entire floor has equal height (figure 7).

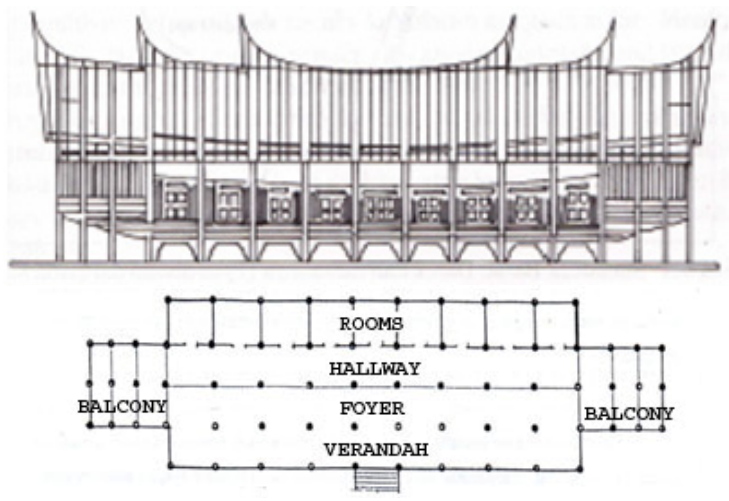

Figure 6: Koto Piliang Minangkabau house.

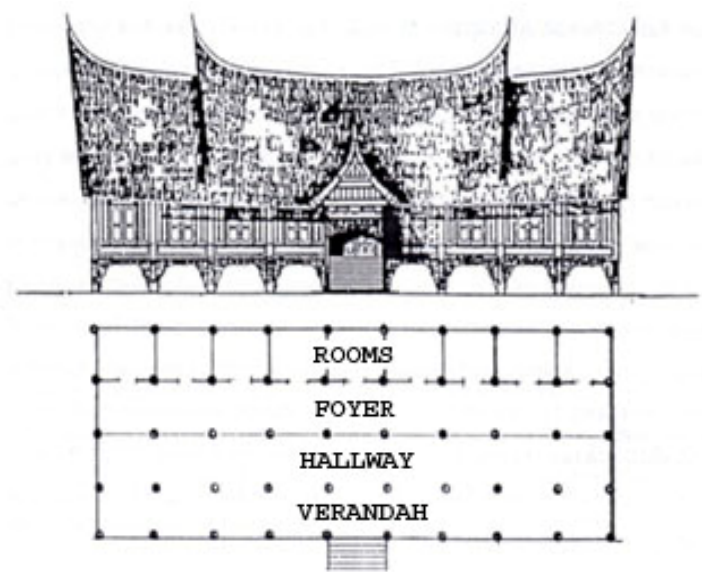

Figure 7: $\quad$ Bodi Caniago Minangkabau house. 
This difference arises from the system of government practiced by the two leaders of the custom systems. Koto Piliang was led by Datuk Ketemenggungan who was bureaucratic while the Bodi Caniago people were led by Datuk Perpatih who practiced democracy. Ultimately, the equal floor levels in the Bodi Caniago house represent the leader and his people of the same status while the different heights of the Kota Piliang house floor level represent a hierarchical people (Idrus [19]).

\section{The Minangkabau house in Negeri Sembilan}

In Negeri Sembilan, the Minangkabau descendants are still holding fast to Perpatih tradition that was subscribed to and practiced by their ancestors (Dom [21]). These houses (figure 8) that are passed on through generations remain to this day and exist around traditional villages in Negeri Sembilan located at upstream and along the rivers found (Idrus [19]) The houses that are still embellished with traditions can be found in districts of Rembau, Kuala Pilah and small parts in Tampin (figure 9). These houses place emphasis more on the verandah, leaving few areas for room spaces. This is the opposite of the house in Western Sumatera.

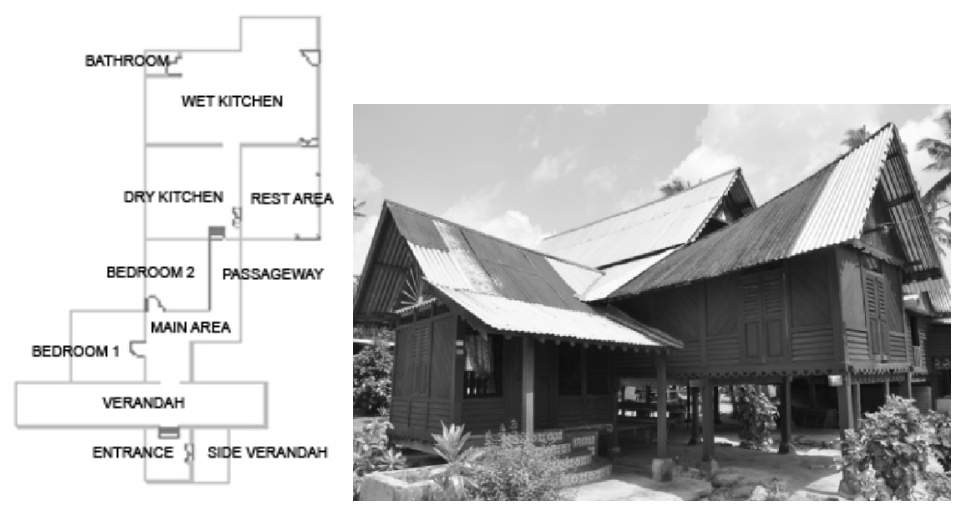

Figure 8: The Minangkabau house in Negeri Sembilan.
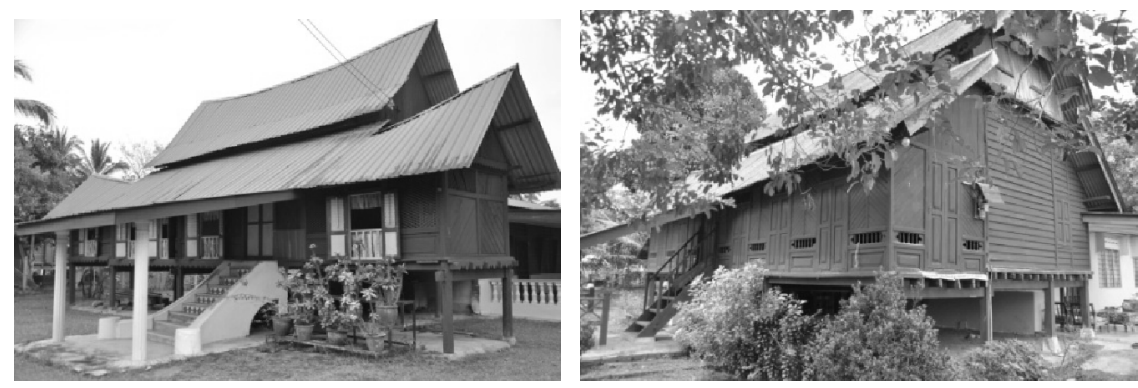

Figure 9: Variations of Minangkabau house in Negeri Sembilan. 


\section{Design with climate}

The Minangkabau houses in both areas apply a simple construction method using local materials. Timber is the main material that made up the main frame of the house. Materials that are used for the construction of the house have always been from sources that are renewable or farmable (figure 10). They contribute to the low impact on the environment as compared to the current modern materials. Furthermore, the materials are accessible and require minimal efforts to acquire them. It requires the interaction between the social and cultural values of the Minangkabau people.

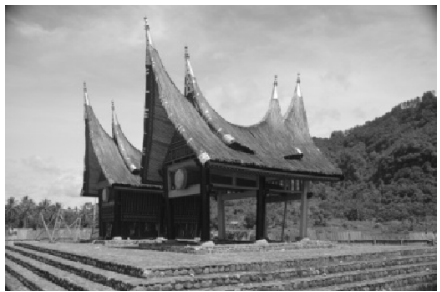

Figure 10: Palm tree frond for roof and bamboo ceiling.

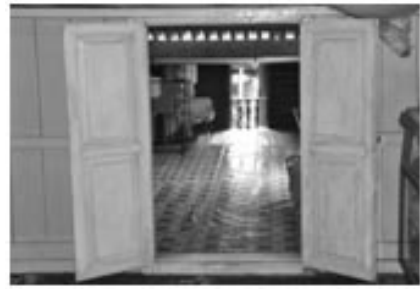

Figure 11: Open interior space.

Internally, the house design is not just for personal use to shelter families but also a place for communal activities, a gathering space for comfort and peace. The breakdown of the interior space planning iterates the various functional spaces. However, all of these spaces function with no definite boundaries (figure 11). Only the activities can determine the use of the spaces (i.e. cooking kitchen, communal activities - main area). The invisible borders create an openness of the interior of the house thus making the internal part seem large and airy. Since there is no ceiling constructed, the roof structure is left open directly to the underside of the roof. A spacious interior is created with almost a double volume due to the open roof configuration. This situation in the interior design of the house provides a cool interior in tropical climes that is governed by sun heat, radiation, rain, wind and humidity. This is fully supported by air vents that are carved out to incorporate aesthetical and functional values to the house (figure 12).
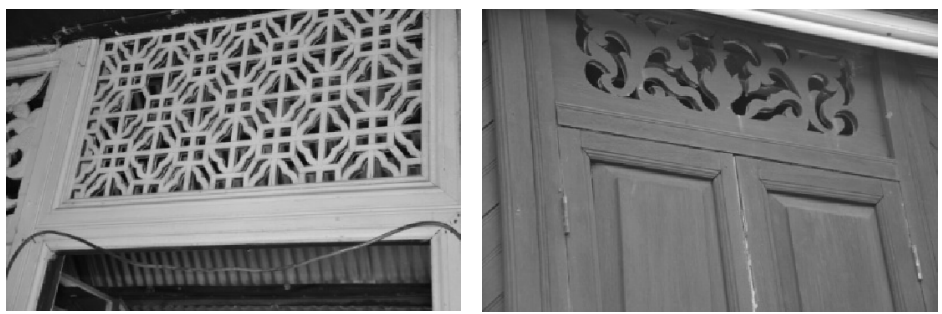

Figure 12: Carved out air vents. 
The carvings are usually motifs derived from animistic beliefs or geometrical patterns based on Islamic teachings. The columns that the house was built on comply with the tropical climate requirements of providing natural cross ventilation underneath the house (figure 13). They are also carved out to reflect the owner's abiding by the customs and traditions. The components of the Minangkabau house go further with not only providing the basic shape and construction of a house but also displaying a lot of embellishments that function just as importantly as the main structure of the house.

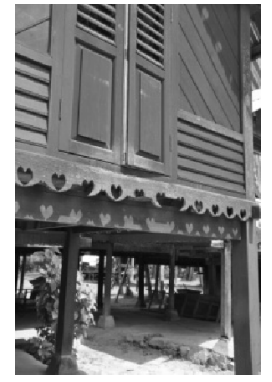

Figure 13: Decorated columns.

\section{Conclusions}

The architectural features of the Minangkabau houses both in the Western Sumatera and Negeri Sembilan are heavily influenced by the local cultural elements. The people from each area have long been practicing similar cultures laced with the matrilineal custom, strong Islamic religious beliefs and the philosophy of nature as a teacher. Ultimately, the environmental factors have also played important roles in the architectural designs although exhibiting variations in style, despite practising the same custom. In Western Sumatera, these differences can be seen clearly on houses either with or without a porch. This is due to the difference in complying with the Koto Piliang and Bodi Caniago traditions of status symbols. In comparing houses from both areas, the obvious difference can be seen in the interior spaces. The Negeri Sembilan house emphasises more on the porch space leaving less area for room spaces. However, the house in Western Sumatera, with it is lack of porch space, maximises the spaces of the rooms. It is believed that the differences in both Minangkabau house designs are due to the matrilineal influence. The mothers and daughters are the heiresses and main residents that have authority to live in the house. They have rights over the design of the house, which is formed in certain appearance. The significance is that the matrilineal group has the cultural privilege through the law of inheritance. The architectural elements of Minangkabau houses reflect the cultural elements and matrilineal tradition which, need to be acknowledged, and have become the glory and upheld strength of the Minangkabau traditional society. The biggest contributions that the Minangkabau house has portrayed are the richness of the sustainable cultural elements and the considerations of the 
house design construction according to environmental and climatic understandings.

\section{References}

[1] Yovita, W. (2012). Budaya Matrilineal Masyarakat Minangkabau Pada Arsitektur Rumah Gadang. Retrieved on February 14, 2012, from http://www.scribd.com/doc/46656529/Budaya-Matrilineal-Masyarakat-

Minangkabau-pada-Arsitektur-Minangkabau.

[2] Hanafi, Z. (1985). Kompedium Sejarah Seni Bina Timur. Pulau Pinang: Universiti Sains Malaysia.

[3] Fox, J. J. (1993). Comparative Perspectives on Austronesian Houses: An Introductory Essay. Canberra: ANU E Press.

[4] Asri, S. (2004). Prinsip-Prinsip Pembinaan Rumah Adat Minangkabau. Johor: Tesis PhD, Universiti Teknologi Malaysia.

[5] Is, S. (2000). Kajian Nilai-Nilai Budaya Pada Ekspresi Tata Ruang Dalam Rumah Adat Minangkabau : Kes Kajian : Luhak Tanah Datar Sumatera Barat. Johor : Tesis PhD, Universiti Teknologi Malaysia.

[6] Soeroto, M. (2005). Pustaka Budaya and Arsitektur. Jakarta: Myrtle Publishing.

[7] Gilbert, K. (2002). Living Contradictions. The Women's Review of Books, Vol. 20, No. 1, 25-26.

[8] Jayatri, A. (2001). Rencana Induk Lanskap Kawasan Wisata Budaya Kompleks Istana Pagaruyung, Sumatera Barat. Bandung: Tesis Sarjana, Institut Pertanian Bogor.

[9] Widya, D. (2001). Kajian Arsitektur Rumah Tinggal Tradisional Minangkabau Nagari Panyalaian Kabupaten Tanah. Semarang: Tesis Sarjana, Universitas Diponegoro.

[10] Adil, B. (1981). Sejarah Negeri Sembilan. Kuala Lumpur: Dewan Bahasa Dan Pustaka.

[11] Kim, T. L., and Zima, N. (1994). Negeri Sembilan Negeri Adat Perpatih. Kuala Lumpur: Goodmark Enterprise.

[12] Ibrahim, N. (1993). Adat Perpatih : Perbezaan Dan Persamaannya Dengan Adat Temenggung. Kuala Lumpur: Fajar Bakti.

[13] Nasroen, M. (1957). Dasar Falsafah Adat Minangkabau. Bandung: Bulan Bintang.

[14] Noah, S.M. (2002). Rekabentuk Penyelidikan : Falsafah, Teori dan Praktis. Serdang: Universiti Putra Malaysia.

[15] Masoed, A. J. (2010, December 19). Tinjauan Tentang Nilai-nilai Dasar Adat Minangkabau . Retrieved on May 7, 2012, from http://dokumentasibuya. blogspot.com /2010/12/tinjauan-tentang-nilai-nilaidasar-adat.html.

[16] Ng, C. (1980). Raising The House Post and Feeding The Husband-Givers in James J.Fox, Inside Austronesian Houses.

[17] Manggis, R. (1971). Minangkabau, Sejarah Ringkas dan Adatnya. Jakarta: Mutiara. 
[18] Hakimy, I. (1978). Rangkaian mustika adat basandi syarak di Minangkabau. Bandung [Indonesia]: Rosda, xii, 233 p.; $21 \mathrm{~cm}$.

[19] Idrus, Y. (1996). Rumah Tradisional Negeri Sembilan : Satu Analisis Seni Bina Melayu. Shah Alam: Fajar Bakti.

[20] Erman, M., Boestami, Moechtar, M. S., Zaiful, A., and Nusjirwan, A. (1981). Rumah Gadang Minangkabau. Sumatera Barat: Proyek Pengembangan Permuseuman Sumatera Barat.

[21] Dom, M. M. (1977). Adat Perpatih dan Adat Istiadat Masyarakat Malaysia. Kuala Lumpur: Federal Publications. 